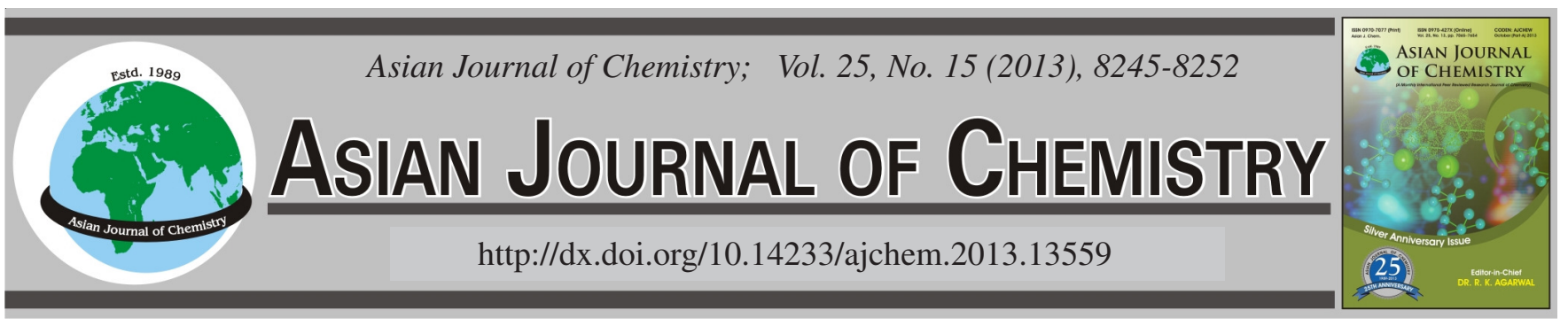

\title{
Adsorption Studies on the Removal of Hexavalent Chromium- Contaminated Wastewater Using Activated Carbon and Bentonite
}

\author{
Salah Abdel Wanees ${ }^{1}$, Abdel Monem M. Ahmed ${ }^{2, *}$, Mohamed S. Adam ${ }^{3}$ and Mamdouh A. Mohamed ${ }^{1, *}$
}

\author{
${ }^{1}$ Department of Chemistry, Faculty of Science, Zagazig University, Zagazig City 44519, Sharkia Province, Egypt \\ ${ }^{2}$ Department of Chemistry, Faculty of Science, Alexandria University, Alexandria, Egypt \\ ${ }^{3}$ Department of Chemistry, Faculty of Science, Sohag University, Sohag, Egypt \\ *Corresponding authors: Tel./Fax: +20 93 2303929; E-mail: mamsahar2020@yahoo.com; profabdelmonem@gmail.com
}

\begin{abstract}
In this study, the adsorption potential of activated carbon and bentonite for removal of $\mathrm{Cr}(\mathrm{VI})$ ions from wastewater has been investigated. The study involves batch type experiments to investigate the effect of initial concentration, adsorbent dose, agitation speed, contact time, temperature and $\mathrm{pH}$ of solution on adsorption process and the optimum conditions were evaluated. The adsorption process has fit pseudosecond order kinetic models. Langmuir and Freundlich adsorption isotherm models were applied to analyze adsorption data and both were found to be applicable to this adsorption process. Thermodynamic parameters, e.g., $\Delta \mathrm{G}^{\circ}, \Delta \mathrm{S}^{\circ}$ and $\Delta \mathrm{H}^{\circ}$ of the on-going adsorption process have also been calculated and the sorption process was found to be endothermic. Finally, it can be seen that bentonite was found to be more effective for the removal of $\mathrm{Cr}(\mathrm{VI})$ than activated carbon, under the same experimental conditions.
\end{abstract}

Key Words: Wastewater, Chromium, Activated carbon, Bentonite, Removal.

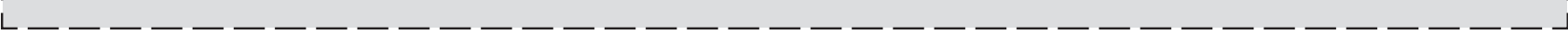

\section{INTRODUCTION}

The pollution of heavy metal ions in the environment is a critical problem because of their toxicity and other adverse effects on the receiving waters and/or soils. They must be removed from wastewater before discharging them into water bodies. Water pollution by chromium is due to both, natural sources and man made activities. Chromium is found in rocks, animals, plants, soils and in volcanic dusts and gases. Various industrial processes such as steel production, electroplating, leather tanning, nuclear power plants, textile industries, wood preservation, anodizing of aluminum, water-cooling and chromate preparation ${ }^{1}$. Discharge chromium containing wastes with varied concentration between 5 and $220 \mathrm{mg} / \mathrm{L}$ into the environment, which contaminates soil and water ${ }^{2,3}$. The world mine production of chromite was estimated at a gross mass of $13 \times 10^{6}$ metric tons in $2002^{4}$. In nature chromium exists in two most stable oxidation states, i.e., trivalent and hexavalent forms in aqueous systems. Although, at trace level, the trivalent form is considered as an essential nutrient ${ }^{5,6}$, hexavalent form of chromium is toxic, carcinogenic and mutagenic in nature ${ }^{7-12}$. The hexavalent form is about 500 times more toxic than trivalent form ${ }^{13}$. Furthermore, $\mathrm{Cr}(\mathrm{VI})$ is highly mobile in soil and aquatic system and also is a strong oxidant capable of being adsorbed by $\operatorname{skin}^{14}$. Considering its toxicity and carcinogenic nature, the maximum levels permitted for trivalent chromium in wastewater $5 \mathrm{mg} / \mathrm{L}$ and for hexavalent chromium are $0.05 \mathrm{mg} / \mathrm{L}^{15,16}$.

The most common methods of removal of $\mathrm{Cr}(\mathrm{VI})$ ions from aqueous system are chemical precipitation, ion exchange, membrane processes, electrodialysis and adsorption ${ }^{17-20}$. Hexavalent chromium usually exists in wastewater as oxyanions such as chromate $\mathrm{CrO}_{4}{ }^{2-}$ and dichromate $\mathrm{Cr}_{2} \mathrm{O}_{7}{ }^{2-}$ and does not precipitate easily using conventional precipitation methods. Ion exchange, reverse osmosis and elctrodialysis are efficient for $\mathrm{Cr}$ (VI) ions removal but the cost is relatively high ${ }^{20}$. Furthermore, chromium removal techniques such as co-precipitation, membrane techniques and solvent extraction are challenged by the removal of lower concentrations of metals from solution ${ }^{21}$. On the other hand, adsorption has been proved to be one of the respective methods, which is simple, selective and economical process for the removal of heavy metal ions from aqueous solution.

In this work two different adsorbents (activated carbon and bentonite) were used for the removal of hexavalent chromium $\left(\mathrm{Cr}^{6+}\right)$ from wastewater. Bentonite is considered by many authors as main candidate in the decontamination and treatment of detrimental metal ions, because of its large specific surface area and high adsorption capacity ${ }^{22-24}$. 
TABLE-1

SURFACE AREA AND PARTICLE SIZE ANALYSIS OF ACTIVATED CARBON AND BENTONITE

\begin{tabular}{|c|c|c|c|c|}
\hline \multirow{3}{*}{$\begin{array}{c}\text { Adsorbents analysis } \\
\text { Surface area (BET) Nova } 2000 \text { Quantachrome }\end{array}$} & \multicolumn{2}{|c|}{ Activated carbon } & \multicolumn{2}{|c|}{ Bentonite } \\
\hline & \multicolumn{2}{|c|}{$931.9 \mathrm{~m}^{2} / \mathrm{g}$} & \multicolumn{2}{|c|}{$119.8 \mathrm{~m}^{2} / \mathrm{g}$ (dry) } \\
\hline & Size (micrometer) & Wt. (\%) & Size (micrometer) & Wt. (\%) \\
\hline \multirow[t]{7}{*}{ Particle size (XRD) Philips PW 1730} & $32-16$ & 2.75 & $>63$ & 1 \\
\hline & $16-8$ & 55.89 & $63-32$ & 1 \\
\hline & $8-4$ & 16.03 & $32-16$ & 2 \\
\hline & $4-2$ & 21.14 & $16-8$ & 3 \\
\hline & $<2$ & 4.19 & $8-4$ & 2 \\
\hline & & & $4-2$ & 4 \\
\hline & & & $<2$ & 87 \\
\hline
\end{tabular}

The objectives of the present study are: (1) to study the effect of contact time of $\mathrm{Cr}^{6+}$ metal ions adsorption on activated carbon and bentonite; (2) to investigate the influence of $\mathrm{pH}$ on the adsorption of $\mathrm{Cr}^{6+}$; (3) to study the adsorption of $\mathrm{Cr}^{6+}$ at different temperatures and to calculate the adsorption thermodynamic parameters (i.e., $\Delta \mathrm{H}^{\mathrm{o}}, \Delta \mathrm{S}^{\mathrm{o}}$ and $\Delta \mathrm{G}^{\mathrm{o}}$ ); (4) to find the effect of adsorbent dose and initial concentration on the adsorption of $\mathrm{Cr}^{6+}$; (5) to describe the experimental data of adsorption isotherms through Langmuir and Freundlich models; (6) to investigate the adsorption properties of $\mathrm{Cr}^{6+}$ and to discuss its adsorption mechanism.

\section{EXPERIMENTAL}

All chemicals used in this present work were either of analytical reagent or laboratory reagent grade and were used as received. Potassium dichromate $(99 \%), \mathrm{H}_{2} \mathrm{SO}_{4}(98 \% \mathrm{w} / \mathrm{w})$ supplied by BDH chemicals Ltd. Distilled water was used in all preparations. Potassium dichromate and deionized water were used to prepare synthetic chromium containing wastewater. Powder activated carbon (PAC) produced from natural origin by ADWIC was used as adsorbent as well as American Wyoming calcium bentonite used in Alexandria Company for Refractories.

Powder activated carbon (PAC) and bentonite (clay) were supplied from ADWIC and Alexandria Company for Refractories, respectively. The surface area and particle size analyses for the two adsorbents were checked (Table-1). Elemental analysis for bentonite was evaluated using X-ray fluorescence (Philips PW 1390) as shown in (Table-2).

TABLE-2

ELEMENTAL ANALYSIS FOR BENTONITE WAS EVALUATED USING X-RAY FLUORESCENCE (PHILIPS PW 1390)

\begin{tabular}{cc|cc}
\hline Oxides (wt. \%) & Bentonite & Oxides (wt. \%) & Bentonite \\
\hline $\mathrm{SiO}_{2}(\%)$ & 55.89 & $\mathrm{Na}_{2} \mathrm{O}(\%)$ & 0.34 \\
$\mathrm{Al}_{2} \mathrm{O}_{3}(\%)$ & 16.03 & $\mathrm{TiO}_{2}(\%)$ & 0.15 \\
$\mathrm{Fe}_{2} \mathrm{O}_{3}(\%)$ & 4.19 & $\mathrm{P}_{2} \mathrm{O}_{5}(\%)$ & 0.086 \\
$\mathrm{CaO}(\%)$ & 3.25 & $\mathrm{SO}_{3}(\%)$ & 0.23 \\
$\mathrm{MgO}(\%)$ & 2.75 & $\mathrm{LOI}(\%)$ & 17.2 \\
$\mathrm{~K} 2 \mathrm{O}(\%)$ & 0.49 & - & - \\
\hline
\end{tabular}

Magnetic hot plate stirrer was used to stir the heavy metal ions solutions with adsorbents (activated carbon or bentonite). A definite volume of heavy metal ions solution with a known initial ions concentration was stirred with a definite amount of adsorbent for certain time at fixed temperature and agitation rate. The $\mathrm{pH}$ values of the solutions were measured by digital $\mathrm{pH}$ meter (Model $\mu \mathrm{pH}$ system-361, India). The metal ion concentration was measured using atomic-absorption spectrophotometer, AAS, (Model, AA55; Varian Inc., USA).

Experimental procedures: Potassium dichromate and redistilled water were used to prepare a stock solution with a concentration of $1000 \mathrm{ppm} \mathrm{Cr}(\mathrm{VI})$ which was diluted for preparation of test solutions. Several solutions with different initial concentrations of potassium dichromate (50, 100, 200, 300 and $400 \mathrm{ppm}$ ) were prepared. The required $\mathrm{pH}$ was adjusted by drop wise addition of $0.1 \mathrm{~N} \mathrm{H}_{2} \mathrm{SO}_{4}$ depending on the acidity of the sample. All experiments were carried out at $25^{\circ} \mathrm{C}$ by adding different amounts of adsorbents $(0.1,0.3,0.5,0.7$ and $1.0 \mathrm{~g}$ ) to different concentrations of $250 \mathrm{~mL}$ of heavy metal ions solution. The agitation rate for all experiments was 200 $\mathrm{rpm}$ and the residence time was $(0,15,30,45,60,75,90$ and $120 \mathrm{~min})$.

$1 \mathrm{~mL}$ of sample was taken from reaction solution and diluted to $10 \mathrm{~mL}$ by redistilled water, adsorbents were then separated from the solution by using filter paper (Whatman No. 40) and the residual $\mathrm{Cr}^{6+}$ ions concentration in the solution was then determined by atomic-absorption spectrophotometer.

The effects of several parameters, such as contact time, initial concentration, adsorbent dose, $\mathrm{pH}$ and temperature on the adsorption of $\mathrm{Cr}(\mathrm{VI})$ ions onto activated carbon and bentonite were studied.

Data analysis: The uptake of $\mathrm{Cr}(\mathrm{VI})$ ions was calculated from the mass balance, which was stated as the amount of solute adsorbed onto the solid. It equals the amount of solute removed from the solution. Mathematically, it can be expressed by eqn. 1 :

$$
\mathrm{q}_{\mathrm{e}}=\frac{\left(\mathrm{C}_{\mathrm{i}}-\mathrm{C}_{\mathrm{e}}\right)}{\mathrm{S}}
$$

where: $\mathrm{q}_{\mathrm{e}}$ the heavy metal ions concentration adsorbed by an adsorbent at equilibrium (mg of metal ions/g of adsorbent). $\mathrm{C}_{\mathrm{i}}$ is the initial concentration of metal ions in the solution $(\mathrm{mg} / \mathrm{L})$. $\mathrm{C}_{\mathrm{e}}$ is the equilibrium concentration or final concentration of metal ions in the solution $(\mathrm{mg} / \mathrm{L})$. S the dosage concentration and it is expressed by eqn. 2 :

$$
\mathrm{S}=\frac{\mathrm{m}}{\mathrm{V}}
$$

where $\mathrm{V}$ is the initial volume of metal ions solution used (L) and $\mathrm{m}$ is the weight of dried used adsorbent $(\mathrm{g})$.

The percentage of adsorption (\%) is calculated using eqn. 3:

$$
\operatorname{Adsorption}(\%)=\left[\frac{\left(\mathrm{C}_{\mathrm{i}}-\mathrm{C}_{\mathrm{e}}\right)}{\mathrm{C}_{\mathrm{i}}}\right] \times 100
$$




\section{RESULTS AND DISCUSSION}

Effect of contact time: The effect of contact time on $\mathrm{Cr}(\mathrm{VI})$ adsorption on both activated carbon and bentonite was investigated to study the rate of $\mathrm{Cr}(\mathrm{VI})$ ions removal (Fig. 1). It is easily seen from Fig. 1 that the percentage removal of $\mathrm{Cr}(\mathrm{VI})$ metal ions increased with increasing the contact time. The \% removal was $73 \%$ for activated carbon and $77 \%$ for bentonite after $120 \mathrm{~min}$. It is clear that, at the beginning $\%$ removal increased rapidly in few minutes, by increasing contact time, \% removal increased lightly and slowly till reach maximum value and this can be explained on the basis that, initially a large number of vacant surface sites may be available for adsorption of metal ions and by time the surface sites become exhausted $^{25}$. These results indicate that the activated carbon and bentonite have a strong capacity for adsorption of $\mathrm{Cr}(\mathrm{VI})$ ions in solutions.

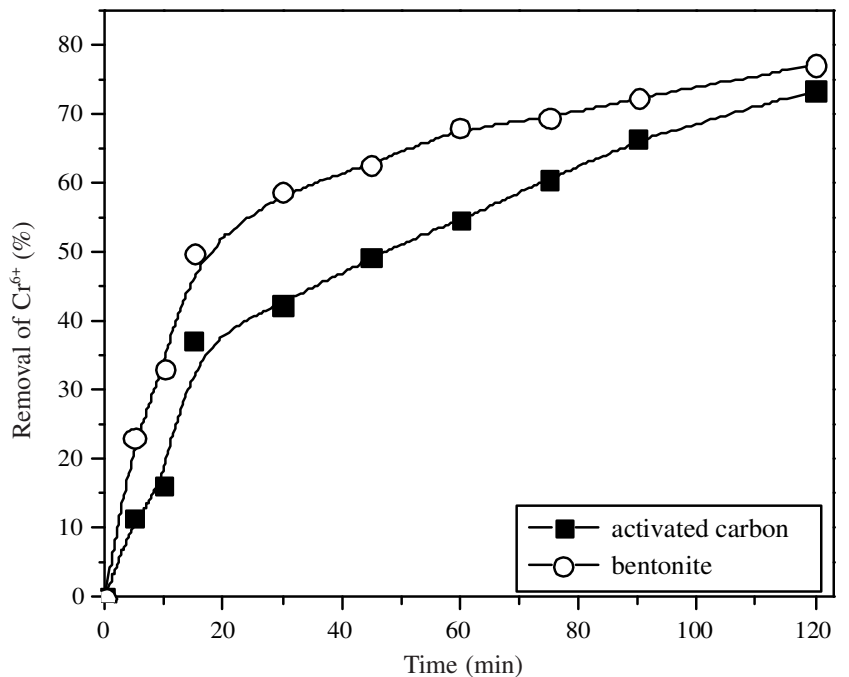

Fig. 1. Effect of contact time on $\mathrm{Cr}^{6+}$ ions removal (conditions; adsorbate initial concentration: $400 \mathrm{mg} / \mathrm{L}$; $\mathrm{pH}$ : 2 ; adsorbents dose: $4 \mathrm{~g} / \mathrm{L}$; agitation speed: $200 \mathrm{rpm}$; temperature: $25^{\circ} \mathrm{C}$ )

Effect of adsorbent dose: The percentage adsorption of $\mathrm{Cr}^{6+}$ ions onto activated carbon and bentonite was studied at different adsorbent doses $(0.4,1.2,2.0,2.8$ and $4.0 \mathrm{~g} / \mathrm{L})$, keeping $\mathrm{pH}(2)$, temperature $\left(25^{\circ} \mathrm{C}\right)$, contact time $(120 \mathrm{~min})$ and initial $\mathrm{Cr}^{6+}$ ions concentration of $(400 \mathrm{mg} / \mathrm{L})$ constant (Fig. 2). The results showed that with increasing in adsorbent dose, the percentage adsorption of $\mathrm{Cr}^{6+}$ was increased and the maximum removal was observed with adsorbent dose $4 \mathrm{mg} / \mathrm{L}$ for activated carbon and bentonite. Increasing the percentage of adsorption with adsorbent dose may be due to the increase in adsorbent surface area and availability of more adsorption $\operatorname{sites}^{26,27}$. But unit adsorption was decreased with increasing in adsorbent dose (Fig. 3). This may be due to overlapping of adsorption sites as a result of overcrowding of adsorbent particles $^{27}$.

Effect of initial chromium(VI) ions concentration: The initial heavy metal ions concentration is an important parameter in adsorption since a certain amount of adsorbent can adsorb a certain amount of heavy metal ions. The percentage removal of $\mathrm{Cr}^{6+}$ was studied by varying $\mathrm{Cr}^{6+}$ concentration from

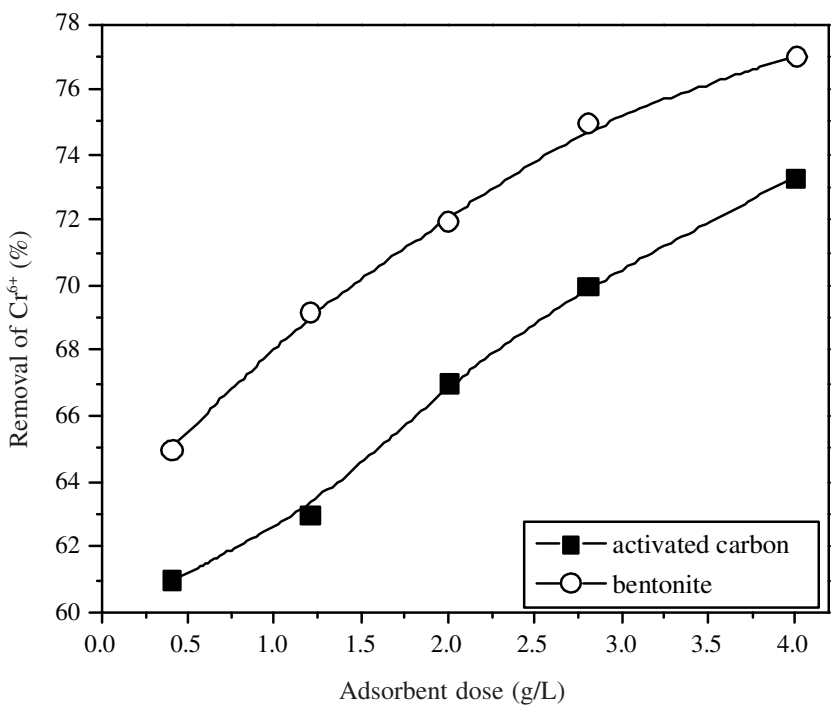

Fig. 2. Effect of variant activated carbon or bentonite adsorbent dosage $(0.4,1.2,2.0,2.8$ and $4.0 \mathrm{~g} / \mathrm{L})$ on the removal of $400 \mathrm{mg} / \mathrm{L} \mathrm{Cr} \mathrm{Cr}^{6+}$ ions from wastewater at contact time: $2 \mathrm{~h}$; temperature: $25^{\circ} \mathrm{C}$; agitation speed: $200 \mathrm{rpm}$

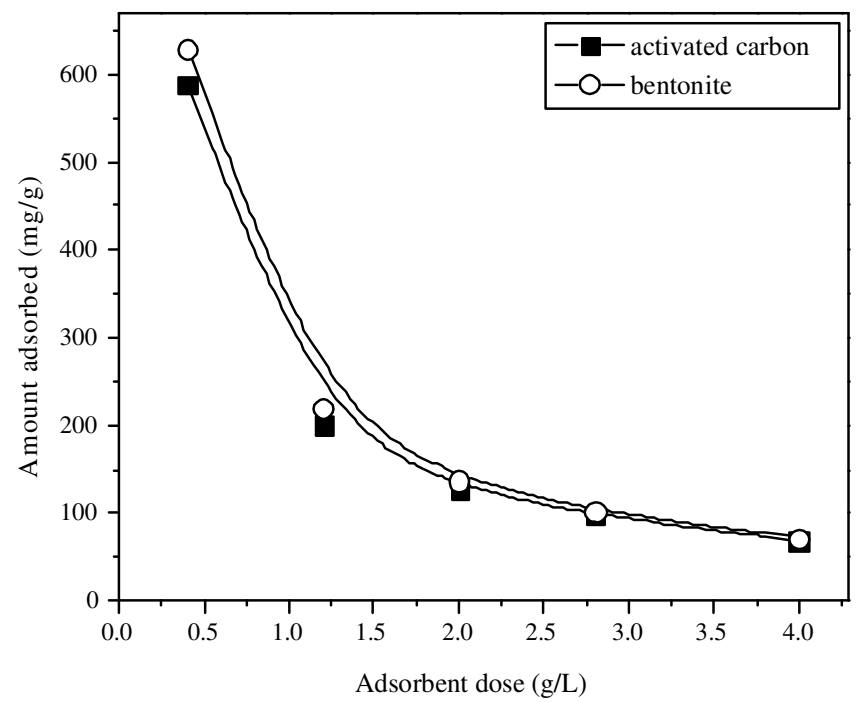

Fig. 3. Effect of variant activated carbon or bentonite adsorbent dosage $(0.4,1.2,2.0,2.8$ and $4.0 \mathrm{~g} / \mathrm{L})$ on the quantity adsorbed for 400 $\mathrm{mg} / \mathrm{L} \mathrm{Cr}^{6+}$ ions from wastewater at contact time: $2 \mathrm{~h}$; temperature: $25^{\circ} \mathrm{C}$; agitation speed: $200 \mathrm{rpm}$

50 to $300 \mathrm{mg} / \mathrm{L}$ with $4 \mathrm{~g} / \mathrm{L}$ adsorbent dose of activated carbon and bentonite at $\mathrm{pH}(2)$, temperature $\left(25^{\circ} \mathrm{C}\right)$ and contact time $(2 \mathrm{~h})$ is illustrated in Fig. 4.

Fig. 4 showed that the percentage $\mathrm{Cr}^{6+}$ ions adsorption was decreased with increasing in initial concentration. But the actual amount of $\mathrm{Cr}^{6+}$ ions adsorbed per unit mass of the adsorbent was increased with increasing in $\mathrm{Cr}^{6+}$ ions concentration in the test solution (Fig. 5). According to these results, the initial $\mathrm{Cr}^{6+}$ ions concentration plays an important role in the adsorption capacities. Higher concentrations of metal ions were used to study the maximum adsorption capacity of adsorbent ${ }^{28,29}$.

Effect of $\mathrm{pH}$ on the uptake of $\mathrm{Cr}^{6+}$ : The $\mathrm{pH}$ of the solution is an important variable which controls the adsorption of the metal ions at the solid-water interface. Hence, the influence 


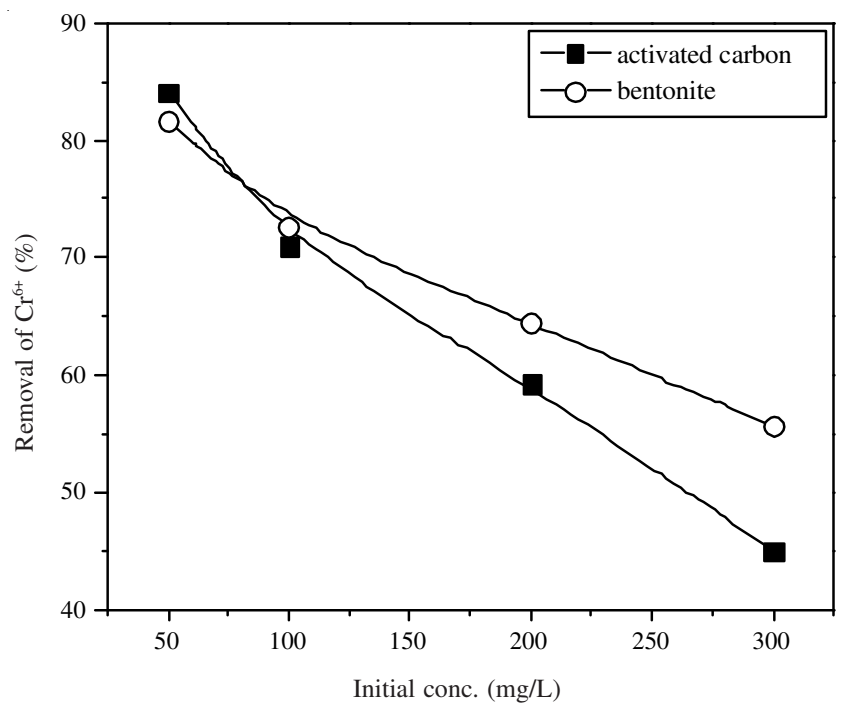

Fig. 4. Effect of initial concentration (namely 50, 100, 200 and $300 \mathrm{mg} / \mathrm{L}$ ) on removal of $\mathrm{Cr}^{6+}$ ions (conditions; adsorbents dose: $4 \mathrm{~g} / \mathrm{L}$; agitation speed: $200 \mathrm{rpm}$; temperature: $\left.25^{\circ} \mathrm{C}\right)$

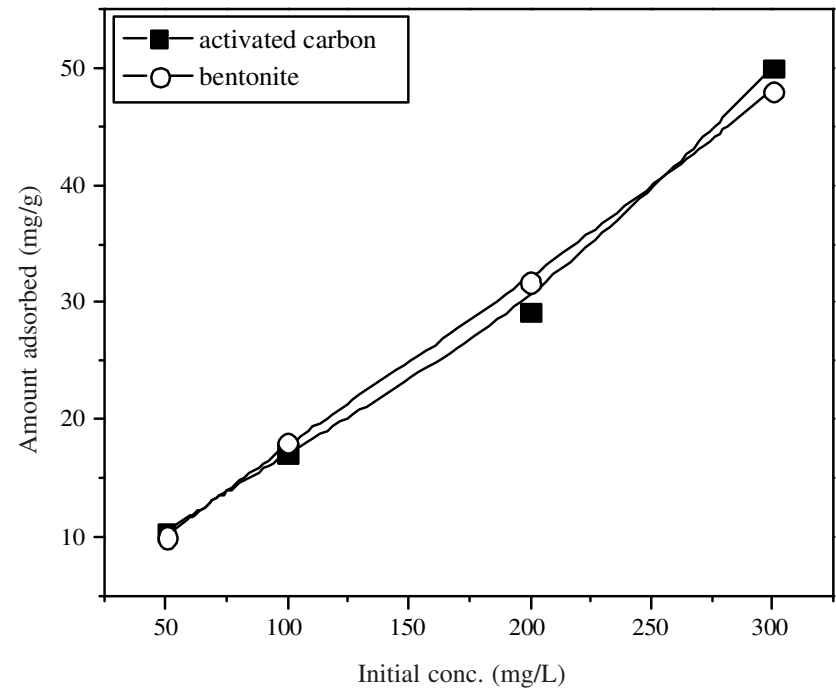

Fig. 5. Effect of initial concentration (namely 50, 100, 200 and $300 \mathrm{mg} / \mathrm{L}$ ) on quantity adsorbed of $\mathrm{Cr}^{6+}$ ions (conditions; adsorbents dose: 4 $\mathrm{g} / \mathrm{L}$; agitation speed: $200 \mathrm{rpm}$; temperature: $25^{\circ} \mathrm{C}$ )

of $\mathrm{pH}$ on the adsorption of $\mathrm{Cr}^{6+}$ ions onto activated carbon and bentonite was examined in the $\mathrm{pH}$ range of 1-4. These results were represented in Fig. 6, which showed that the adsorption capacities of $\mathrm{Cr}^{6+}$ ions onto both adsorbents increased significantly with decreasing $\mathrm{pH}$ value and the maximum removals of $\mathrm{Cr}^{6+}$ ions by both adsorbents for contact time $(2 \mathrm{~h})$ were carried out at $\mathrm{pH}$ (2). The improved removal of chromium(VI) at low $\mathrm{pH}$ is probably due to reduction of hexavalent chromium to trivalent chromium ions ${ }^{30}$, eqn. 4 .

$$
\mathrm{Cr}_{2} \mathrm{O}_{7}^{2-}+14 \mathrm{H}^{+}+6 \mathrm{e}^{-1} \rightarrow 2 \mathrm{Cr}^{3+}+7 \mathrm{H}_{2} \mathrm{O}
$$

At low $\mathrm{pH}$, there is presence of a large number of $\mathrm{H}^{+}$ions, which in turn neutralize the negatively charged adsorbent surface, thereby reducing hindrance to the diffusion of dichromate ions ${ }^{31}$.

Effect of temperature: Fig. 7 indicates the effect of temperature on the removal efficiency of $\mathrm{Cr}^{6+}$ ions from wastewater

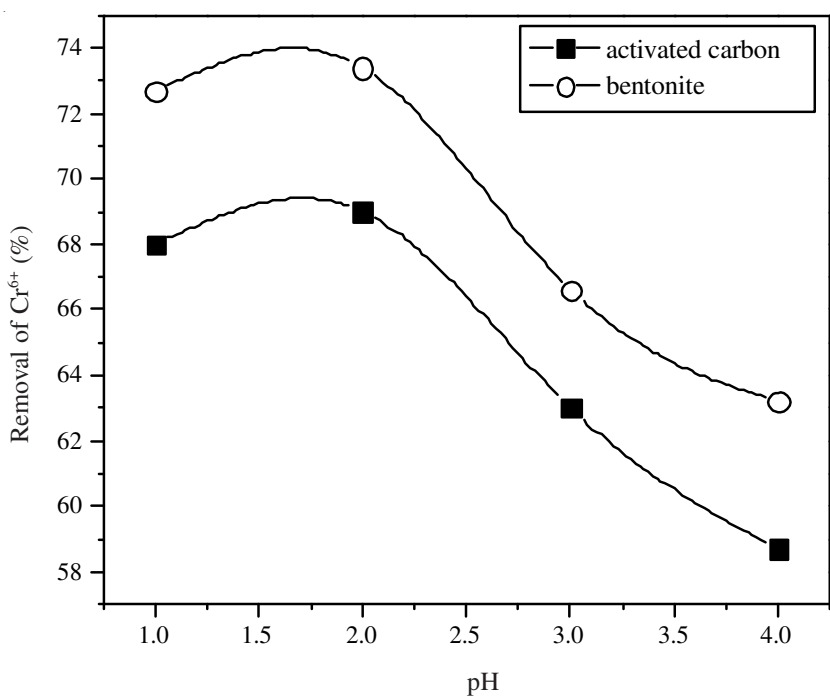

Fig. 6. Effect of $\mathrm{pH}$ for the adsorption of $\mathrm{Cr}(\mathrm{VI})$ ions onto activated carbon and bentonite at $25^{\circ} \mathrm{C}$

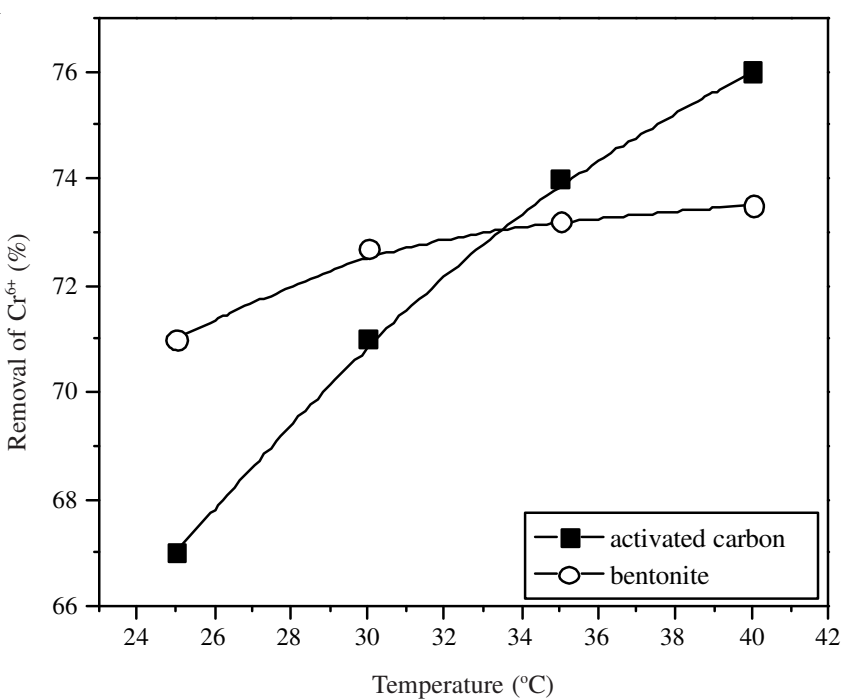

Fig. 7. Effect of temperature between 25 and $40{ }^{\circ} \mathrm{C}$ for the removal of $\mathrm{Cr}^{6+}$ ions from wastewater (conditions; adsorbate initial concentration: $400 \mathrm{mg} / \mathrm{L}$; pH: 2.0; adsorbents dose: $4 \mathrm{~g} / \mathrm{L}$; agitation speed: 200 rpm; contact time: $2 \mathrm{~h}$ )

using activated carbon and bentonite. Four different temperatures were considered in this study $\left(25,30,35\right.$ and $\left.40^{\circ} \mathrm{C}\right)$. The figure showed that the removal efficiency increased by increasing the temperature, where the maximum adsorption (ca. $76 \%$ ) is achieved at $40{ }^{\circ} \mathrm{C}$ in case of activated carbon. The augmentation of the removal efficiency by stepping up the temperature are due to: Firstly, the higher temperatures activate the metal ions for enhancing adsorption at the coordinating sites of the adsorbent and the metal cations became more faster ${ }^{32,33}$. Secondly, acceleration of some originally slow step(s) and creation of some new activation sites on the adsorbent surface ${ }^{34}$. Herein, the phenomenon can be observed in both adsorbents, but activated carbon is affected much higher than in case bentonite Fig. 7.

Adsorption kinetics: Adsorption kinetics describe the solute uptake rate which intern control the residence time and hence the size of adsorption equipment. The experimental results for the adsorption of $\mathrm{Cr}^{6+}$ ions onto activated carbon 
and bentonite showed rapid initial adsorption rate followed by a slower rate. Initially, the adsorption sites are open and the metal ions interact easily with the sites and hence a higher rate of adsorption is observed. Further, the driving force for adsorption (the concentration difference between the bulk solution and the solid-liquid interface) is higher initially and this leads to a higher adsorption rate. However, after the initial period, slow adsorption may be due to slower diffusion of solute into the interior of the adsorbent. Several adsorption kinetics models have been developed to understand the adsorption kinetics and rate limiting step ${ }^{35-38}$.

The following models have been widely used ${ }^{37,38}$ Largergren pseudo-first order model can expressed by eqns. 5 and 6:

$$
\begin{gathered}
\frac{\mathrm{dq}}{\mathrm{dt}}=\mathrm{k}_{1}\left(\mathrm{q}_{\mathrm{e}}-\mathrm{q}\right) \\
\ln \left(\mathrm{q}_{\mathrm{e}}-\mathrm{q}\right)=\ln \mathrm{q}_{\mathrm{e}}-\mathrm{k}_{1} \mathrm{t}
\end{gathered}
$$

The pseudo-second order model is given by eqns. 7 and 8:

$$
\begin{aligned}
& \frac{\mathrm{dq}}{\mathrm{dt}}=\mathrm{k}_{2}\left(\mathrm{q}_{\mathrm{e}}-\mathrm{q}\right)^{2} \\
& \frac{\mathrm{t}}{\mathrm{q}}=\frac{\mathrm{t}}{\mathrm{q}_{\mathrm{e}}}+\frac{1}{\mathrm{k}_{2} \mathrm{q}_{\mathrm{e}}^{2}}
\end{aligned}
$$

where $\mathrm{q}$ and $\mathrm{q}_{\mathrm{e}}$ are the amount of $\mathrm{Cr}^{+6}$ metal adsorbed per unit weight of adsorbent $(\mathrm{mg} / \mathrm{g})$ at time $\mathrm{t}$ and at equilibrium, respectively and $\mathrm{k}_{1}$ and $\mathrm{k}_{2}$ are the adsorption rate constants. The initial adsorption rate (h) is equal to $\mathrm{k}_{1} \mathrm{q}_{\mathrm{e}}$ and $\mathrm{k}_{2} \mathrm{q}_{\mathrm{e}}{ }^{2}\left(\mathrm{mg} \mathrm{g}^{-1}\right.$ $\min ^{-1}$ ) for first and second order models, respectively.

The applicability of the above two models can be examined by each linear plot of $\ln \left(\mathrm{q}_{\mathrm{e}}-\mathrm{q}\right) v s . \mathrm{t}$ and $(\mathrm{t} / \mathrm{q}) v s . \mathrm{t}$, respectively and are represented in Figs. 8(a,c) and 8(b,d), respectively. To quantify the applicability of each model, the correlation coefficient, $\mathrm{R}^{2}$, was calculated from these plots. The linearity of these plots indicates the applicability of the two models. However, the correlation, $\mathrm{R}^{2}$, showed that the pseudo-second order model, fits better the experimental data $\left(\mathrm{R}^{2}>0.990\right)$ than the pseudo-first order model $\left(\mathrm{R}^{2}\right.$ in the range of $0.888-0.964)$.

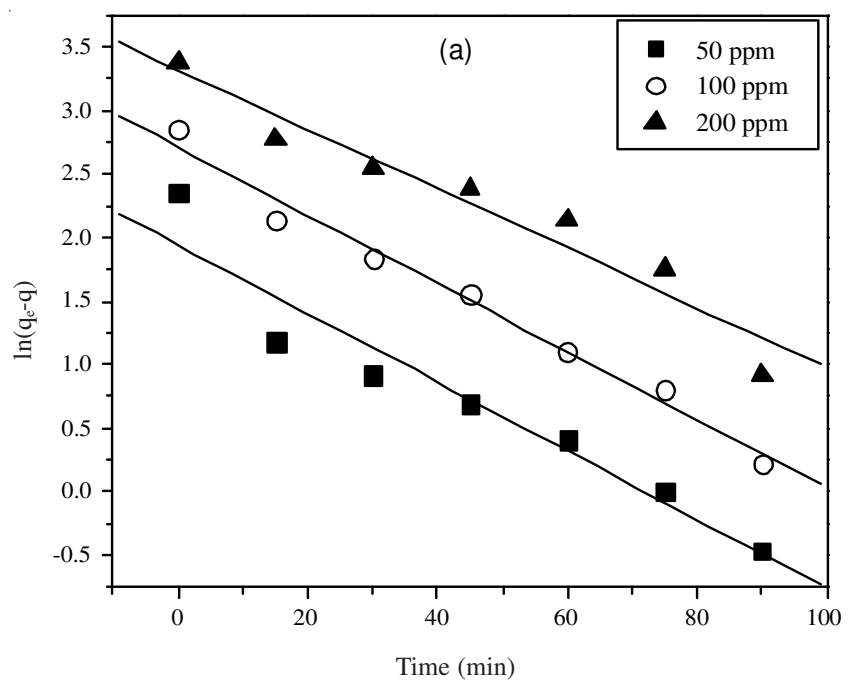

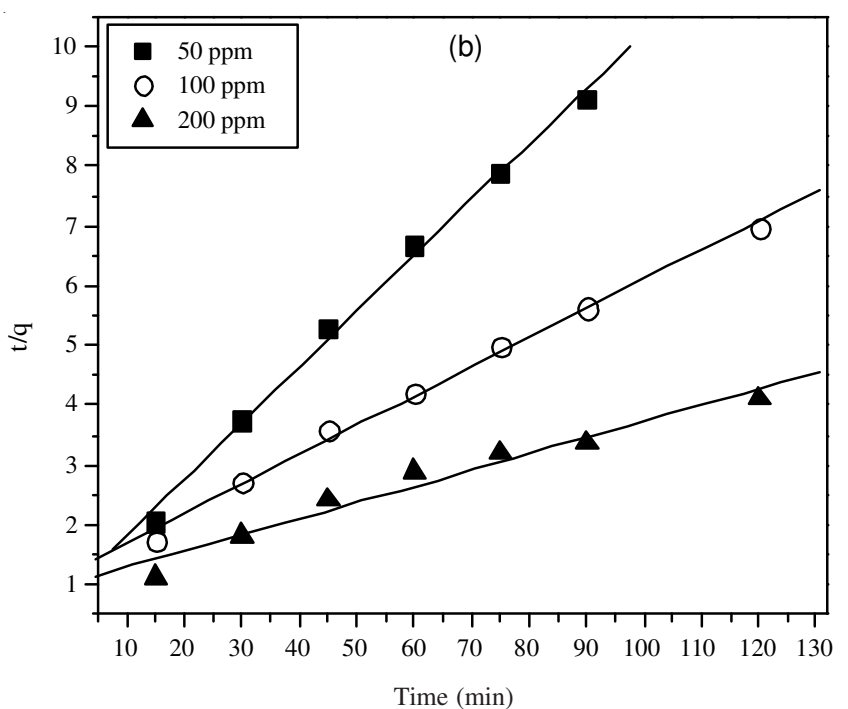
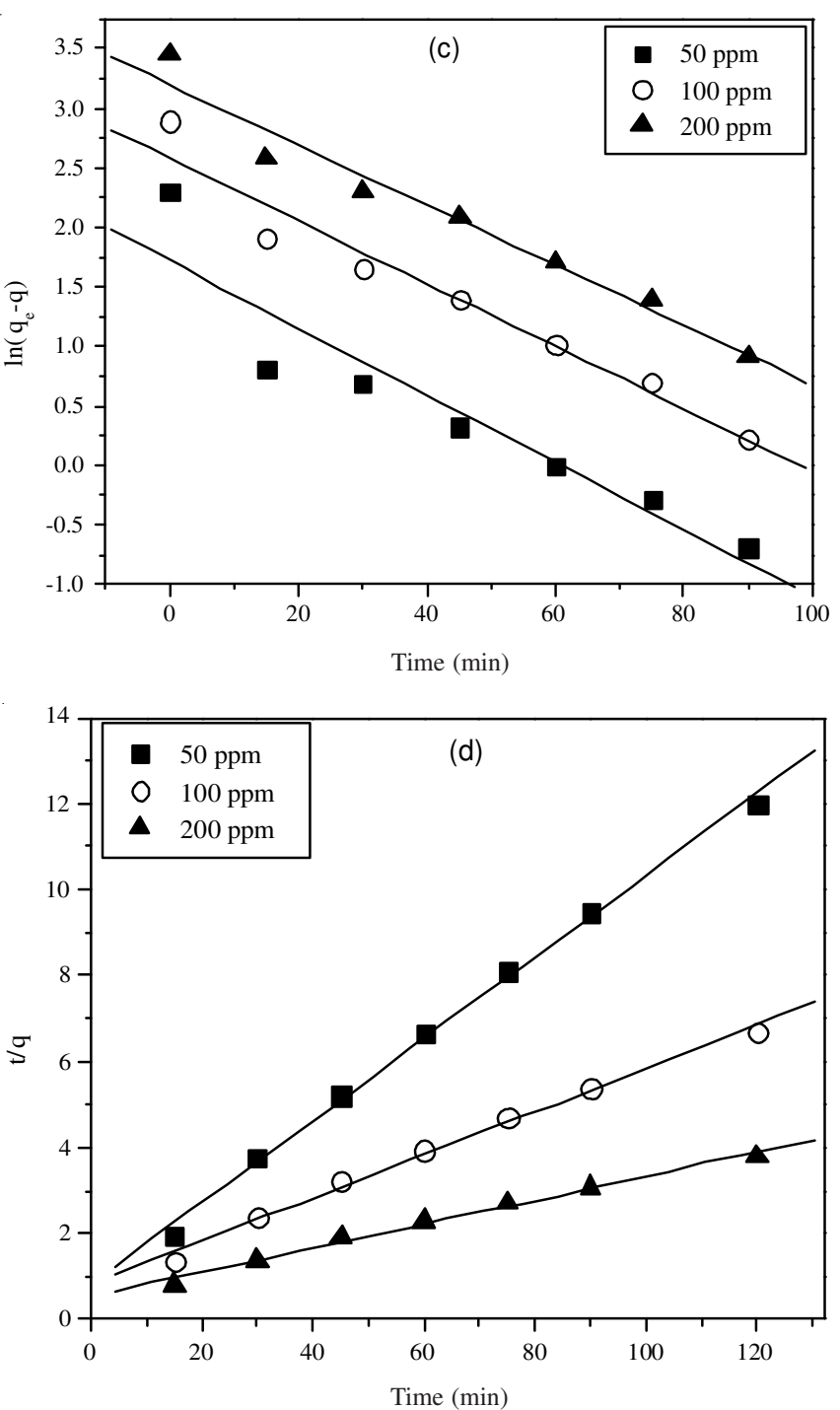

Fig. 8. Pseudo-first order kinetic plots for the adsorption of $\mathrm{Cr}^{6+}$ ions onto: (a) activated carbon and (c) bentonite. Pseudo-second order kinetic plots for the adsorption of $\mathrm{Cr}^{6+}$ ions on: (b) activated carbon and (d) bentonite. Initial concentrations: 50, 100 and 200 ppm; pH: 2.0; adsorbents dose: $4 \mathrm{~g} / \mathrm{L}$; agitation speed: $200 \mathrm{rpm}$; temperature: $25^{\circ} \mathrm{C}$

The kinetic parameters calculated are shown in Table- 3 . It has been found that the equilibrium sorption capacities 


\begin{tabular}{|c|c|c|c|c|c|c|c|c|}
\hline \multirow{3}{*}{ Adsorbent } & \multicolumn{7}{|c|}{$\begin{array}{c}\text { TABLE-3 } \\
\text { ADSORPTION KINETICS MODEL RATE CONSTANTS FOR ADSORPTION OF Cr }{ }^{6+} \text { IONS ONTO }^{\circ} \\
\text { ACTIVATED CARBON AND BENTONITE AT VARIOUS CONCENTRATIONS AT } 25^{\circ} \mathrm{C}\end{array}$} & \\
\hline & \multirow{2}{*}{$\begin{array}{c}\mathrm{C}_{\mathrm{o}} \\
(\mathrm{mg} / \mathrm{L})\end{array}$} & \multirow{2}{*}{$\begin{array}{l}q_{\mathrm{e}} \text { exp. } \\
(\mathrm{mg} / \mathrm{g})\end{array}$} & \multicolumn{3}{|c|}{ Lagergren first-order } & \multicolumn{3}{|c|}{ Pseudo-second-order } \\
\hline & & & $\mathrm{K}_{1}\left(\min ^{-1}\right)$ & $\mathrm{q}_{1}(\mathrm{mg} / \mathrm{g})$ & $\mathrm{R}^{2}$ & $\mathrm{k}_{2}\left(\mathrm{~g} \mathrm{~g}^{-1} \min ^{-1}\right)$ & $\mathrm{q}_{2}(\mathrm{mg} / \mathrm{g})$ & $\mathrm{R}^{2}$ \\
\hline \multirow{3}{*}{$\begin{array}{l}\text { Activated } \\
\text { carbon }\end{array}$} & 50 & 10.5 & $2.7 \times 10^{-2}$ & 6.95 & 0.9276 & $9.7 \times 10^{-3}$ & 10.7 & 0.9954 \\
\hline & 100 & 17.25 & $2.6 \times 10^{-2}$ & 15.0 & 0.9840 & $1.9 \times 10^{-3}$ & 20.4 & 0.9934 \\
\hline & 200 & 29.25 & $2.3 \times 10^{-2}$ & 27.7 & 0.9371 & $7.2 \times 10^{-4}$ & 36.9 & 0.9597 \\
\hline \multirow{3}{*}{ Bentonite } & 50 & 10.0 & $2.8 \times 10^{-2}$ & 5.6 & 0.8851 & $1.1 \times 10^{-2}$ & 10.5 & 0.9968 \\
\hline & 100 & 18.0 & $2.7 \times 10^{-2}$ & 13.2 & 0.9585 & $3.0 \times 10^{-3}$ & 18.9 & 0.9934 \\
\hline & 200 & 31.75 & $2.5 \times 10^{-2}$ & 24.5 & 0.9642 & $1.4 \times 10^{-3}$ & 35.7 & 0.9912 \\
\hline
\end{tabular}

determined using second-order model were in agreement with the experimentally determined equilibrium sorption capacities. Also, the rate constant decreased with the solution concentration increasing.

In general, the adsorption reaction is known to proceed through the following three steps: (1) transfer of adsorbate from bulk solution to adsorbent surface, which is usually mentioned as diffusion, (2) migration of adsorbate into pores and (3) interaction of adsorbate with available sites on the interior surface of pores.

Adsorption isotherms: Several models have been used in the literature to describe the experimental data of adsorption isotherm. The Langmuir and Freundlich models are the most frequently employed to describe equilibrium ${ }^{39}$. The Langmuir isotherm is based on the theoretical principle that only a single adsorption layer exists on an adsorbent and it represents the equilibrium distribution of metal ions between the solid and liquid phases. The basic assumption of the Langmuir adsorption process is the formation of a monolayer of adsorbate on the outer surface of the adsorbent and after that no further adsorption takes place. The Langmuir-type isotherm remains to be the most widely used for practical application. The Langmuir isotherm for pure component adsorption can be obtained from eqn. 9:

$$
\frac{\mathrm{C}_{\mathrm{e}}}{\mathrm{q}_{\mathrm{e}}}=\frac{1}{\left(\mathrm{q}_{\max } \mathrm{b}\right)}+\left(\frac{1}{\mathrm{q}_{\max }}\right) \mathrm{C}_{\mathrm{e}}
$$

where $\mathrm{q}_{\max }$ is the maximum metal ions uptake per unit mass of adsorbent $(\mathrm{mg} / \mathrm{g})$, which is related to the adsorption capacity and $b$ is Langmuir constant $(\mathrm{L} / \mathrm{mol})$ which is exponentially proportional to the heat of adsorption and related to the adsorption intensity. Therefore, a plot of $\mathrm{C}_{\mathrm{e}} / \mathrm{q}_{\mathrm{e}}$ versus $\mathrm{C}_{\mathrm{e}}$ gives a straight line of the slop $1 / \mathrm{q}_{\max }$ and intercept $1 /\left(\mathrm{q}_{\max } \mathrm{b}\right)$ as shown in Fig. 9.

Zeldowitsch ${ }^{39}$, assuming an exponentially decaying function of site density with respect to heat of adsorption and obtained the classical empirical isotherm (eqn. 10):

$$
\ln \mathrm{q}_{\mathrm{e}}=\ln \mathrm{K}_{\mathrm{f}}+\frac{1}{\mathrm{n}} \ln \mathrm{C}_{\mathrm{e}}
$$

This is known as Freundlich isotherm. The Freundlich adsorption isotherm is an indicator of the extent of heterogeneity of the adsorbent surface, where the Freundlich constants $\mathrm{K}_{\mathrm{f}}$ and $\mathrm{n}$, which respectively indicating the adsorption capacity and the adsorption intensity, were calculated from the intercept and slope of the plot of $\ln \mathrm{q}_{\mathrm{e}}$ versus $\ln \mathrm{C}_{\mathrm{e}}$ as shown in Fig. 10.

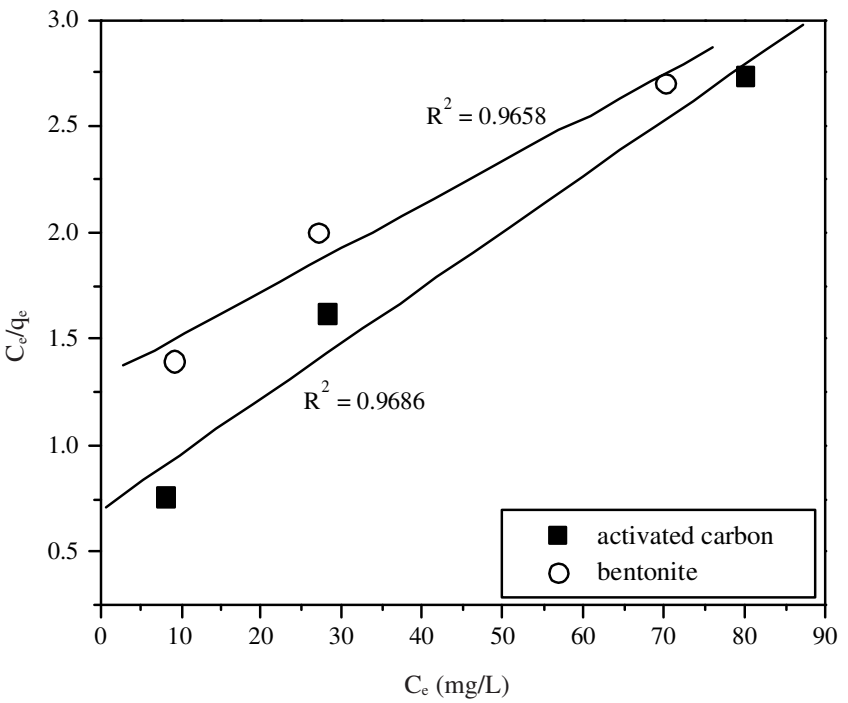

Fig. 9. Langmuir adsorption isotherm for $\mathrm{Cr}^{6+}$ ions adsorption by activated carbon and bentonite at constant temperature $25^{\circ} \mathrm{C}$ and contact time $2 \mathrm{~h}$

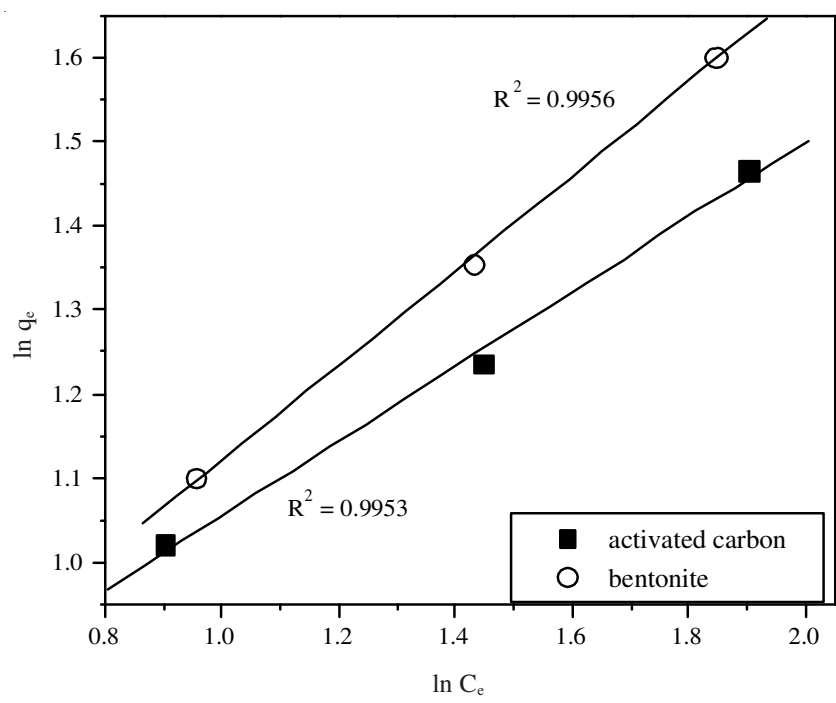

Fig. 10. Freundlich adsorption isotherm for $\mathrm{Cr}^{6+}$ ions adsorption by activated carbon and bentonite at constant temperature $25^{\circ} \mathrm{C}$ and contact time $2 \mathrm{~h}$

This Freundlich type behaviour is indicative of surface heterogeneity of the adsorbents, i.e., the adsorptive sites (surface of activated carbon and bentonite) are made up of small heterogeneous adsorption patches that are homogeneous in themselves. The activation of adsorption sites takes place, leading to increased adsorption probably through the surface exchange mechanism. 
The calculated results of Langmuir and Freundlich isotherm constants are given in Table-4. It can be seen that the Freundlich model yields a much better fit than the Langmuir model, when the $\mathrm{R}^{2}$ values are compared in Table- 4 . This suggests that the boundary layer thickness is increased. The Freundlich constant $\mathrm{K}_{\mathrm{f}}$ indicates the sorption capacity of the sorbent. From Table-4, the values of $\mathrm{K}_{\mathrm{f}}$ are 1.84 and 1.58 for activated carbon and bentonite, respectively.

Furthermore, the value of $\mathrm{n}$ is 2.26 and 1.78 for activated carbon and bentonite, respectively. It is noted that the values of $\mathrm{n}$ are bigger than 1, reflecting the favorable adsorption. On the other hand, the $\mathrm{q}_{\max }$ and the adsorption intensity values of bentonite are higher than activated carbon. The calculated $b$ values indicate the interaction forces between bentonite surface and $\mathrm{Cr}^{6+}$ ions are stronger than in case of activated carbon, this means that the bentonite is more powerful adsorbent than activated carbon. These results indicate that both adsorbents have a very strong adsorption capacity towards $\mathrm{Cr}^{6+}$ ions.

Thermodynamic parameters: Thermodynamic parameters such as free energy $\left(\Delta \mathrm{G}^{\mathrm{o}}\right)$, enthalpy $\left(\Delta \mathrm{H}^{\mathrm{o}}\right)$ and entropy $\left(\Delta \mathrm{S}^{\mathrm{o}}\right)$ changes of adsorption can be evaluated from the following equations $(11,12)$ :

$$
\begin{gathered}
\mathrm{K}_{\mathrm{c}}=\frac{\mathrm{A}_{\mathrm{Ae}}}{\mathrm{C}_{\mathrm{e}}} \\
\Delta \mathrm{G}^{\mathrm{o}}=-\mathrm{RT} \ln \mathrm{K}_{\mathrm{c}}
\end{gathered}
$$

where $\mathrm{K}_{\mathrm{c}}$ is the equilibrium constant and $\mathrm{C}_{\mathrm{Ae}}$ and $\mathrm{C}_{\mathrm{e}}$ (both in $\mathrm{mg} / \mathrm{L}$ ) are the equilibrium concentrations for solute on the sorbent and in the solution, respectively. The $\mathrm{K}_{\mathrm{c}}$ values are used in eqns. 11 and 12 to determine the $\Delta \mathrm{G}^{\mathrm{o}}, \Delta \mathrm{H}^{\mathrm{o}}$ and $\Delta \mathrm{S}^{\mathrm{o}}$, the $\mathrm{K}_{\mathrm{c}}$ may be expressed in terms of the $\Delta \mathrm{H}^{\mathrm{o}}\left(\mathrm{kj} \mathrm{mol}^{-1}\right)$ and $\Delta \mathrm{S}^{\mathrm{o}}\left(\mathrm{kj} \mathrm{mol}^{-1} \mathrm{~K}^{-1}\right)$ as a function of temperature, eqn. 13:

$$
\ln \mathrm{K}_{\mathrm{c}}=-\frac{\Delta \mathrm{H}^{\mathrm{o}}}{\mathrm{RT}}+\frac{\Delta \mathrm{S}^{\mathrm{o}}}{\mathrm{R}}
$$

Thermodynamic parameters such as free energy of sorption $\left(\Delta \mathrm{G}^{\mathrm{o}}\right)$, the heat of sorption $\left(\Delta \mathrm{H}^{\mathrm{o}}\right)$ and standard entropy $\left(\Delta S^{\circ}\right)$ changes during the sorption process were calculated using eqns. 11 and 12 on a temperature range of $25-40{ }^{\circ} \mathrm{C}$ at initial concentration $50 \mathrm{mg} / \mathrm{L}$ of $\mathrm{Cr}^{6+}$ ions and dose $4 \mathrm{~g} / \mathrm{L}$ for activated carbon and bentonite. The values of $\Delta \mathrm{H}^{\circ}$ and $\Delta \mathrm{S}^{\circ}$ (Table-5) were obtained from the slope and intercept of a plot of $\ln \mathrm{K}_{\mathrm{c}}$ versus $1 / \mathrm{T}$ (Fig. 11).

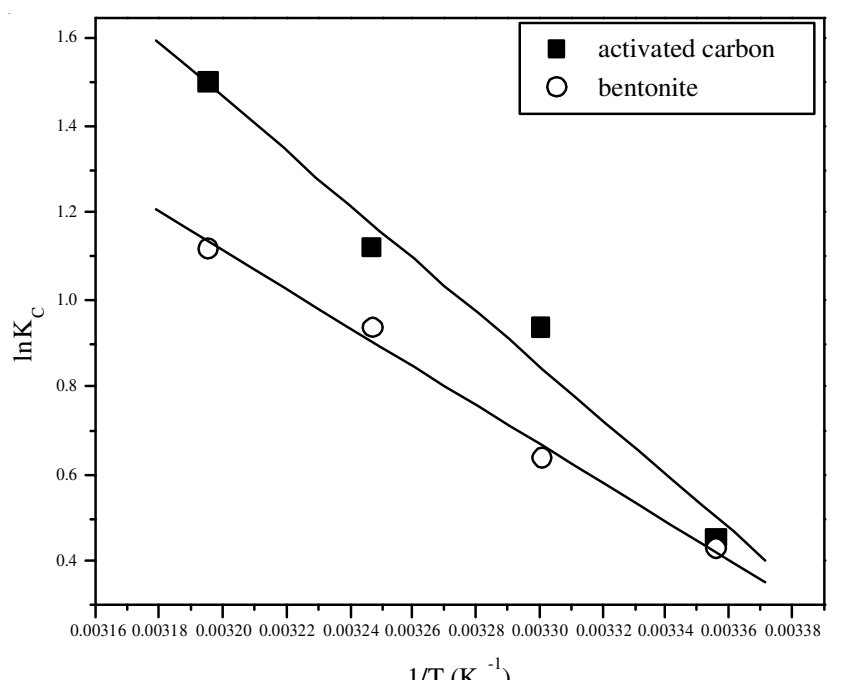

$$
1 / \mathrm{T}\left(\mathrm{K}^{-1}\right)
$$

Fig. 11. Plot of $\ln \mathrm{K}_{\mathrm{C}}$ versus $1 / \mathrm{T}$ for $\mathrm{Cr}^{6+}$ ions adsorption onto activated carbon and bentonite for $50 \mathrm{mg} / \mathrm{L}$ initial concentration at constant adsorbents dose: $4 \mathrm{~g} / \mathrm{L}$

The negative values of $\Delta \mathrm{G}^{\mathrm{o}}$ indicate the spontaneous nature of the process and more negative value with increase of temperature showed that an increased in temperature favours the sorption process. The positive values of $\Delta \mathrm{H}^{\circ}$ indicated that the sorption process was endothermic in nature and the positive values of $\Delta \mathrm{S}^{\mathrm{o}}$ showed the increased randomness at solid/solution interfaces during the adsorption of metal ions onto both adsorbents and also reflected the affinity of activated carbon and bentonite toward $\mathrm{Cr}^{+6}$ ions under consideration. It is also suggested that the positive values of entropy indicated some structural changes in the adsorbate and adsorbent ${ }^{40-42}$.

\section{Conclusion}

Both adsorbents can be successfully used for removing of chromium(VI) ions from wastewater. The maximum adsorption percentages of $\mathrm{Cr}(\mathrm{VI})$ ions using both adsorbents were achieved within $2 \mathrm{~h}$. The adsorption percentages of $\mathrm{Cr}^{6+}$ ions increased sharply by increasing adsorbent dose. As the initial concentration of ions increased the percentage removal using activated carbon and bentonite decreased. The best temperature for the maximum adsorption is found to be $30-40{ }^{\circ} \mathrm{C}$ for activated carbon, while the adsorption using bentonite is less affected by increasing temperature. The maximum removals of $\mathrm{Cr}(\mathrm{VI})$ ions by both adsorbents were carried out at $\mathrm{pH} 2$. The pseudo-second kinetic order model is suitable for describing

\begin{tabular}{lcccccc} 
& \multicolumn{9}{c}{ TABLE-4 } \\
& \multicolumn{3}{c}{ LANGMUIR AND FREUNDLICH ISOTHERM CONSTANTS FOR THE ADSORPTION OF Cr ${ }^{6+}$} \\
& \multicolumn{3}{c}{ IONS ONTO ACTIVATED CARBON AND BENTONITE AT $25^{\circ} \mathrm{C}$} \\
\hline \multirow{2}{*}{ Adsorbent } & \multicolumn{3}{c}{ Langmuir isotherm constants } \\
\cline { 2 - 8 } & $\mathrm{q}_{\max }(\mathrm{mg} / \mathrm{g})$ & $\mathrm{b}(\mathrm{L} / \mathrm{mol})$ & $\mathrm{R}^{2}$ & \multicolumn{3}{c}{ Freundlich isotherm constants } \\
\hline Activated carbon & 38.17 & 0.0252 & 0.9686 & 1.8446 & 2.26 & 0.9953 \\
Bentonite & 48.83 & 0.0377 & 0.9658 & 1.5826 & 1.78 & 0.9995 \\
\hline
\end{tabular}

TABLE-5

THERMODYNAMIC PARAMETERS FOR THE ADSORPTION OF Cr(VI) IONS ONTO ACTIVATED CARBON AND BENTONITE

\begin{tabular}{lcccccc}
\hline \multirow{2}{*}{ Adsorbent } & \multirow{2}{*}{$\Delta \mathrm{H}^{\mathrm{o}}\left(\mathrm{kj} \mathrm{mol}^{-1}\right)$} & \multirow{2}{*}{$\Delta \mathrm{S}^{\circ}\left(\mathrm{kj} \mathrm{mol}^{-1} \mathrm{~K}^{-1}\right)$} & \multicolumn{5}{c}{$\Delta \mathrm{G}^{\circ}\left(\mathrm{kj} \mathrm{mol}^{-1}\right)$} \\
\cline { 4 - 7 } & & & $25^{\circ} \mathrm{C}$ & $30^{\circ} \mathrm{C}$ & $35^{\circ} \mathrm{C}$ & $40^{\circ} \mathrm{C}$ \\
\hline Activated carbon & 51.45 & 0.1776 & -1.24 & -2.12 & -3.00 & -3.89 \\
Bentonite & 36.72 & 0.1268 & -1.06 & -1.70 & -2.33 & -2.71 \\
\hline
\end{tabular}


the adsorption system. The obtained experimental data has been well described by Langmuir and Freundlich isotherm models into both activated carbon and bentonite.

Different thermodynamic parameters, viz., $\Delta \mathrm{H}^{\mathrm{o}}, \Delta \mathrm{S}^{\mathrm{o}}$ and $\Delta \mathrm{G}^{\mathrm{o}}$ have also been evaluated and it has been found that the sorption was feasible, spontaneous and endothermic in nature. The positive value of the entropy change, suggested the increased randomness.

\section{REFERENCES}

1. N.R. Jyothi, N.A.M. Farook, M.Y. Cho and J. Shim, Asian J. Chem., 23, 4125 (2013).

2. S.K. Ouki and R.D. Neufeld, J. Chem. Technol. Biotechnol., 70, 3 (1997).

3. H.S. Altundogan, Process Biochem., 40, 1443 (2005).

4. J.F. Papp, US Geological Survey (USGS) Mineral commodity summaries, In eds.: Guertin et al., Chromium(VI) Handbook, CRC Press, p. 2005 (2003); http://minerals.er.U.S.G.S.gov/minerals/pubs/commodity/chromium/.

5. G. Rojas, J. Silva, J. A. Flores, A. Rodriguez and M. L'Maldonado, Sep. Purif. Technol., 44, 31 (2005).

6. B.J. Alloway, Heavy Metals in Soils, Blackie Academic and Professional, London, edn. 2, p. 368 (1995).

7. I. Dupont and E. Guillon, Environ. Sci. Technol., 37, 4235 (2003)

8. US, Department of Health and Human Services, Toxicological Profile for Chromium, Public Health Services Agency for Toxic Substances and Diseases Registry, Washington, DC (1991).

9. M. Cieslak-Golonka, Polyhedron, 15, 3667 (1995).

10. T. Norseth, Environ. Health Perspectives, 40, 121 (1981).

11. C.R. Myers, J.M. Myers, B.P. Carstens and W.E. Antholine, Toxic Subst. Mechan., 19, 25 (2000).

12. A. Zhitkovich, G. Quievryn, J. Messer, Z. Motylevich, Metal Toxicity, 110, 729 (2002)

13. Z. Kowalski, J. Hazard. Mater, 37, 137 (1994).

14. I.B. Singh and D.R. Singh, Environ. Technol., 23, 85 (2002).

15. F.N. Acar and E. Malkoc, Bioresour. Technol., 94, 13 (2004).

16. Bureau of Indian Standards, IS: 10500-1991.

17. J.W. Patterson, Wastewater Treatment Technology, Ann Arbor Science Publishers, Inc., New York, USA (1977).

18. G. Tiravanti, D. Petrluzzelli and R. Passino, Water Sci. Technol., 36, 197 (1997).
19. S. Dahbi, M. Azzi and M. de la Guardia, Fresenius J. Anal. Chem., 363, 404 (1999).

20. C.C. George, Electroplating Wastewater Pollution Control Technology, Noyes Publications, Park Ridge, pp. 30-39 (1985).

21. M. Valix, W.H. Cheung and K. Zhang, J. Hazard. Mater., B135, 395 (2006).

22. S.H. Lin and R.S. Juang, J. Hazard. Mater., 92, 315 (2002).

23. S.C. Tsai, S. Ouyang and C.N. Hsu, Appl. Radiat. Isot., 54, 209 (2001).

24. M.H. Al-Qunaibit, W.K. Mekhemer and A.A. Zaghloul, J. Colloid Interf. Sci., 283, 316 (2005).

25. Y.B. Zhan, A. Shukla, S. Shukls and K.L. Dorris, J. Hazard. Mater., 80, 33 (2000).

26. C. Namasivayam, K. Kadirvelu and M. Kumuthu, Bioresour. Technol., 64, 77 (1998).

27. U.K. Garg, M.P. Kaur, V.K. Garg and D. Sud, Hazard. Mater., 140, 60 (2007).

28. K. Mohanty, M. Jha, B.C. Meikap and M.N. Biwas, Chem. Eng. J., 117, 71 (2006)

29. T. Karthikeyan, S. Rajgopal and L.R. Miranda, J. Hazard. Mater., B124, 192 (2005)

30. Anon, Standard Methods for the Examination of Water and Wastewater, Washington, DC, USA, edn. 19 (1995).

31. D.C. Sharma and C.F. Forster, Bioresour. Technol., 49, 31 (1994).

32. S. Babel and T.A. Kurniawan, J. Hazard. Mater., B97, 219 (2003).

33. V.J. Inglezakis, M.D. Loizidou and H.P. Grigoropoulou, J. Colloid Interf. Sci., 275, 570 (2004).

34. (a) P.A. Domenico and F.W. Schwartz, Physical and Chemical Hydrogeology, John Wiley and Sons, New York, edn. 1 (1990); (b) L.N. Reddi and H.I. Inyang, Geo-Environmental Engineering Principles and Applications, Marcel Decker Inc. New York (2001); (c) O. Nitzsche and H. Vereecken, Mine Water Environ., 21, 15 (2002).

35. S. Ricordel, S. Taha, I. Cisse and G. Dorange, Sep. Purif. Technol., 24, 389 (2001).

36. I. Uzun and F. Guzel, Turk. J. Chem., 24, 291 (2000).

37. S. Lagergren, Handlingar, 24, 1 (1898).

38. Y.S. Ho and G. Mckay, Process Biochem., 34, 451 (1999).

39. J. Zeldowitsch, Acta Physiochim. URSS, 1, 364 (1934).

40. H.S. Altundogan, S. Altundogan, F. Tumen and M. Bildik, Waste Mange., 20, 761 (2000).

41. H.G. Fuhrman, J.C. Tjell and D. Mcconchie, Environ. Sci. Technol., 38, 2428 (2004).

42. M. Ajmal, R.A.K. Rao, S. Anwar, J. Ahmed and R. Ahmed, Bioresour. Technol., 86, 147 (2003). 